\title{
Expression of Human Bone-related Proteins in the Hematopoietic Microenvironment
}

Michael W. Long, J. Lynn Williams, and Kenneth G. Mann*

Division of Hematology/Oncology, Department of Pediatrics, University of Michigan, Ann Arbor, Michigan 48109; and the ${ }^{*}$ Department of Biochemistry, University of Vermont, Burlington, Vermont 05405

\begin{abstract}
Given the intimate relationship between bone and bone marrow, we hypothesized that the human bone marrow may function as a source (or reservoir) of bone-forming progenitor cells. We observed a population of cells within the bone marrow which produce bone-specific or bone-related proteins. The production of these proteins was developmentally regulated in human long-term bone marrow cell cultures; the bone proteinproducing cells (BPPC) are observed under serum-free, shortterm culture conditions, respond to bone-related and not hematopoietic growth factors, and are derived from a population of low-density, nonadherent, My10-negative (or low My10 density), marrow cells (My10 is an antigen found on most hematopoietic progenitor cells). Cultivation of marrow-derived BPPC in secondary, serum-containing cultures results in their differentiation into osteoblastlike cells. At this stage of development, BPPC produce an extracellular matrix which incorporates both bone-related proteins and radiolabeled calcium. Human bone marrow BPPC thus represent a newly described cell phenotype important to both bone and hematopoietic cell biology. (J. Clin. Invest. 1990. 86:1387-1395.) Key words: hematopoiesis • osteopoiesis • bone proteins • bone-gla-protein - osteonectin
\end{abstract}

\section{Introduction}

The hematopoietic microenvironment influences the growth and differentiation of hematopoietic cells. Although poorly understood, this microenvironment is comprised of soluble regulatory factors, cellular elements, and extracellular components. Soluble factor production within this microenvironment is restricted to the stromal .cells $(1,2)$. Such cells are defined as nonhematopoietic components of bone marrow, e.g., connective tissue, vascular, or neural elements. In longterm bone marrow cultures the maintenance of hematopoiesis is dependent upon the establishment of an intact layer of adherent (stromal) cells. Such adherent cell layers elaborate soluble factors and deposit extracellular matrix which, in turn, influence hematopoietic proliferation and differentiation $(1,3)$.

Presented in part to the American Society of Hematology, 1989.

Address correspondence and reprint requests to Michael W. Long, Ph.D., M7510 MSRB I, Box 0684, University of Michigan, Ann Arbor, MI 48109.

Received for publication 22 February 1990 and in revised form 11 April 1990.

J. Clin. Invest.

(c) The American Society for Clinical Investigation, Inc 0021-9738/90/11/1387/09 \$2.00

Volume 86, November 1990, 1387-1395
Little information is available concerning the intimate relationship between the bone marrow and its surrounding tissue: the bone. The available data demonstrate that bone marrow stromal cells respond to bone growth factors in vitro (increasing the numbers of alkaline phosphatase-positive cells) $(4,5)$, that stromal cells (or stromal cell lines) generate osteoid in vivo $(6,7)$, and that cells of osteoclastic potential are found in the marrow (vide infra). However, these studies do not establish the lineage derivation and/or hierarchy of such cells. Similarly, the few studies on bone formation address only its indirect relation to bone marrow development, showing that bone formation in in vivo models is followed by marrow formation (8-10). Additionally, either type of in vitro model shows limited degrees of bone formation, if any. In particular, the use of postfetal mesenchymal tissue to generate bone progenitor cells results in chrondrogenesis but is often inadequate for osteogenesis (11). Thus, information concerning the cellular activation signals and intracellular processing during bone formation is limited.

One of the central issues concerning bone formation regards the developmental lineages of the bone cell types, namely the osteoblast and the osteoclast. There is adequate evidence to suggest that osteoblasts arise from mesenchymal cell populations and that osteoclasts are derived from bloodborn monocyte/macrophage cells. Fischman and Hay first demonstrated that monocytes fused to form osteoclasts in regenerating newt limbs (12). Although the role of macrophage fusion remains controversial $(4,13)$, further evidence for the blood-born origin of the osteoclast was pioneered by LeDouarin using a chick:quail chimera in which nuclear morphology allows clear distinction of cell derivation. These studies conclusively demonstrated that osteoblasts and osteocytes are derived from the limb bud mesenchyma, whereas osteoclasts arise from blood-born hematopoietic cells $(14,15)$. The importance of these observations was subsequently shown by the successful cure of osteopetrosis utilizing bone marrow transplantation in both animals (16) and humans (17). While such data conclusively show the hematogenous origin of osteoclasts, little knowledge exists on the nature or location of the stem cell population(s) capable of differentiating into bone-forming osteoblasts.

A number of proteins, isolated from demineralized bone, are involved in bone formation. Osteonectin $(\mathrm{ON})^{1}$ is a $32-\mathrm{kD}$ protein which binds calcium, hydroxyapatite, and collagen,

1. Abbreviations used in this paper: BGP, bone-gla-protein; BPPC, bone protein-producing cell; CFC-F, fibroblast, colony-forming cell; ECM, extracellular matrix; $\alpha_{2}$ HS-GP, alpha ${ }_{2} \mathrm{HS}$ glycoprotein; LTBMC, long-term bone marrow cell culture; NALD, nonadherent low density; ON, osteonectin; SAOS2-P80, 80-kD cell surface protein isolated from SAOS osteosarcoma cell line; TGF- $\beta$, transforming growth factor-beta. 
and thus may initiate nucleation of the mineral phase of bone deposition (18). Cellular localization of osteonectin message reveals its presence in a variety of developing tissues (19). However, it is present in its highest levels in bones of the axial skeleton, skull, and the blood platelet (megakaryocyte) (20). Bone $\gamma$-carboxy glutamic acid-containing protein (BGP, osteocalcin) is a vitamin $\mathrm{K}$-dependent, 5,700-D calcium binding bone protein which is specific for bone and may regulate $\mathrm{Ca}^{2+}$ deposition $(18,21)$.

We utilized monoclonal antibodies to bone-related proteins $(22,23)$ as phenotypic probes of the hematopoietic microenvironment. We report that bone proteins are produced in human long-term bone marrow cell cultures, and that the marrow-derived cells producing bone proteins proliferate in response to regulators of bone development but not hematopoietic growth factors. Finally, marrow-derived bone proteinproducing cells are capable of osteoblastlike differentiation.

\section{Methods}

Marrow cell preparation and culture. Human bone marrow aspirates were obtained from normal volunteers after informed consent. Longterm bone marrow cultures (LTBMC) were established exactly as described by Kaplan and Gartner (24). For immunolocalization, two to three coverslips were placed in each LTBMC culture and removed weekly for immunocytochemistry (see below).

For short-term (7-d) assays, human bone marrow cells were subjected to density and adherence separation techniques as described previously $(25,26)$. Marrow cells were density-separated on FicollHypaque, and adherent cells were depleted by two rounds of plastic adherence. Importantly, these nonadherent, low-density (NALD) cells do not contain megakaryocytes or platelets. The former are low density in Ficoll and thus not recovered in the mononuclear cell density band. Both residual megakaryocytes and platelets are removed by the subsequent two rounds of plastic adherence. The resultant NALD cells were cultured in serum-free cultures of supplemented McCoy's 5A media (25) containing 1\% ITS-plus (Collaborative Research, Bedford, MA). Cultures were established in LabTek tissue culture chamber slides (8 chambers per slide, Miles Laboratories Inc., Naperville, IL), and incubated for $7 \mathrm{~d}$ at $33^{\circ} \mathrm{C}$ in $7 \% \mathrm{CO}_{2}$. TGF- $\beta$ (Collaborative Research, Bedford, MA) was kept in stock solution per manufacturer's instructions and diluted in McCoy's media immediately before use.

Culture of bone protein producing cells (BPPC). BPPC are cultivated for $7 \mathrm{~d}$ under serum-free conditions as described above. In serum-stimulation studies the adherent cells are removed by incubating in trypsin/EDTA (Grand Island Biologicals, Grand Island, NY) for $30 \mathrm{~min}$ at $37^{\circ} \mathrm{C}$, and the trypsin inactivated by adding equal volumes of FCS. The adherent cells are washed twice in McCoy's media, serum-stimulated by the addition of $10 \% \mathrm{FCS}$, and recultivated for an additional $7 \mathrm{~d}$ as above. Cells are trypsinized and replated to reduce cell density; equivalent results are observed if serum is added directly to the primary cultures and the cells grown in situ.

Radioimmunoassay and immunochemistry. Bone antigen expression was determined by solid-phase RIA as we have described elsewhere $(25,27)$ using monoclonal antibodies to human bone-related proteins: osteonectin, BGP, and SAOS2-P80, all at $10 \mu \mathrm{g} / \mathrm{ml}$. Bone-related protein antibodies $(22,28)$ were localized by immunoperoxidase cytochemistry utilizing an avidin-biotin system previously described by this laboratory $(27,29)$.

${ }^{45}$ Calcium incorporation into extracellular matrix. BPPC were cultivated under serum-free conditions, and serum-stimulated on day 7 as described above. On days 3, 6, and 8 post-serum stimulation, the suspension and adherent cells were removed, washed three times with calcium-free PBS, and metabolically labeled with $50 \mu \mathrm{Ci}^{45} \mathrm{Ca}^{2+}$ (as ${ }^{45} \mathrm{Ca}^{2+}$; Amersham Corp., Arlington Heights, IL; sp act $733 \mathrm{mBq} / \mathrm{Mg}$ ) for $60 \mathrm{~min}$ at $37^{\circ} \mathrm{C}$. After calcium equilibration, labeled cells were washed free of unincorporated calcium, resuspended in tissue culture medium (RPMI 1640, Gibco, Grand Island, NY), reestablished in the original cultures, and allowed to incorporate cellular ${ }^{45} \mathrm{Ca}^{2+}$ into the extracellular matrix (ECM) for $60 \mathrm{~min}$ at $33^{\circ} \mathrm{C}$. Subsequently, cells/ ECM were removed with trypsin/EDTA (as in Fig. 3), cells pelleted by centrifugation, and ${ }^{45} \mathrm{Ca}^{2+}$ incorporation into the trypsin/EDTA extractable ECM determined by scintillation counting. Trypsin-resistant ECM was removed by Triton X-100 extraction as described previously $(30,31)$ and counted similarly.

\section{Results and Discussion}

Expression of bone proteins in human long-term marrow cultures. Human LTBMC were examined for the production of the bone-related proteins: ON, BGP, and for SAOS2-P80, a membrane-specific antigen present on cells of the human osteosarcoma cell line SAOS2 (23). Immunocytochemical analysis of LTBMC indicates that each was present in a phenotypically distinct subpopulation of bone marrow stromal cells. Osteonectin was found within the cytoplasm of fibroblastlike cells as intracellular granules which are often concentrated at the cell periphery (Fig. 1). These ON-positive cells were scattered throughout the developing hematopoietic foci. Production of BGP and SAOS2-P80 (latter not shown) was limited in distribution to a subpopulation of mononuclear cells, which often appeared in clusters, and localized as a diffuse intracellular deposition (Fig. 2).

Kinetic analysis of bone protein production in human LTBMC shows that BGP-positive cells are observed within 1 wk of culture. At this time, BGP-containing cells are scattered throughout the cultures as small (10-50 cells) clusters, suggesting a clonal evolution of BGP-producing cells. These BGP-positive clusters contain from 20 to $40 \%$ antigen-positive cells. After 2-3 wk, BGP-containing cells are seen to redistribute to the peripheral regions of the developing hematopoietic foci (Fig. 2 B). Eventually (weeks 4-6), BGP is deposited within the extracellular matrix (not shown). Osteonectin production in these cultures remains restricted to fibroblastlike cells which are intermingled with developing hematopoietic cells. Like BGP, ON-positive cells later redistribute to the periphery of developing hematopoietic foci. To confirm the osteal nature of these cells, parallel cultures were stimulated with 1,25-dihydroxy vitamin $D_{3}\left(10^{-10}-10^{-9} \mathrm{M}\right)$. These cultures show both accelerated development of the marrow stromal layer and enhanced production of BGP (data not shown).

Proliferation of bone protein-producing cells (BPPC) in serum-free marrow cell cultures. The nature of the cells producing bone protein (BPPC), were also examined in shortterm ( $1 \mathrm{wk}$ ), serum-free cultures utilizing NALD human bone marrow cells as target cells. Immunocytochemical data indicated that cells containing each of the two bone-related cytoplasmic proteins (ON, BGP), as well as $\alpha_{2} \mathrm{HS}$ glycoprotein, and the membrane-specific SAOS2-P80 were generated from antigen-negative input cells, and that these proteins are not present as membrane-bound serum contaminants. In unstimulated cultures, $\sim 6-7 \%$ of the total cultured cells were BGP or SAOS2-P80 positive and $2 \%$ contained ON. Although NALD cells were used to initiate the cultures, the BPPC observed on day 7 were an adherent cell population. In all cases, the cells bearing these antigens resembled the BGP-positive mononuclear cells observed in LTBMC (re: Fig. $2, A-C$ ). We next 

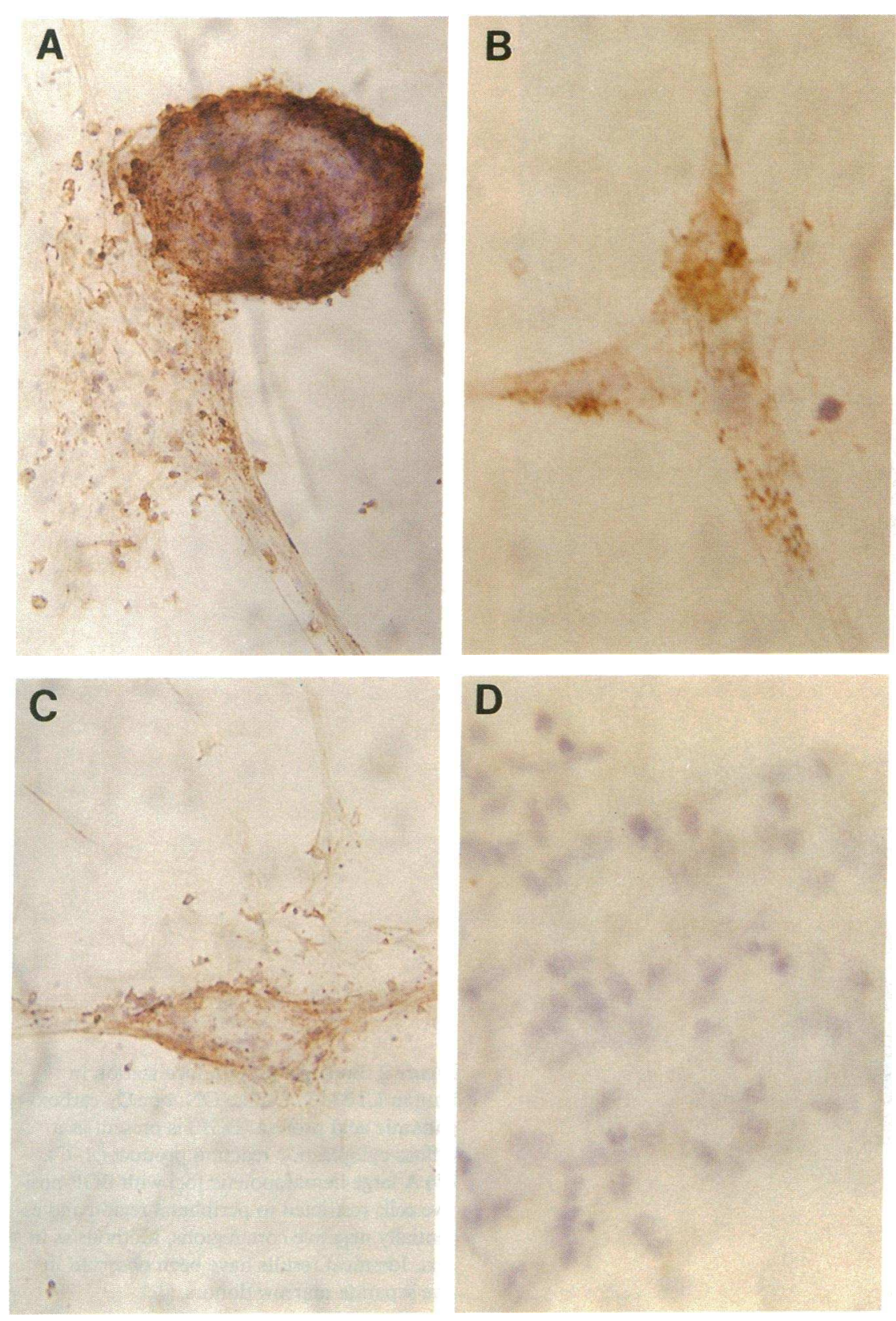

Figure 1. Localization of osteonectin in human LTBMC. Bone-related protein antibodies $(22,28)$ localized by immunoperoxidase cytochemistry utilizing an avidin-biotin system $(27,29)$. ( $A$ ) Large hematopoietic foci $(100 \times)$ plus adjacent stromal cells positive for osteonectin (ON). Note the concentration of ON-positive cells at the periphery of the foci, and scattered positive cells throughout. Such foci do not exist in input cells which are $\mathrm{ON}$ negative and monodispersed. ( $B$ and $C$ ) Cellular localization $(400 X)$ in a fibroblastlike cell. Note granular reaction product which is typical of osteonectin localization. (D) Secondary antibody control (i.e., without antiosteonectin). examined cultures ( $n=4$ separate bone marrow donors) in which both NALD cells and plastic-adherent cells were utilized as target cells in short-term, serum-free cultures. Again, cells capable of producing bone proteins and membrane-specific antigens were restricted to NALD populations. Adherent input cells (i.e., stromal cells isolated from unfractionated marrow by plastic adherence) did not generate antigen-positive cells.

Expression of MY 10 antigen on bone protein producing cells (BPPC). Two alternative approaches were taken to examine the expression of the hematopoietic progenitor cell antigenic marker MY 10 (32) on cells capable of producing bone proteins. The first approach was to subject input NALD cells to a cytotoxicity assay, realizing that the anti-MY 10 is an IgG $_{1}$ isotype (which weakly binds complement), and that a lack of cytotoxic effect would be inconclusive. However, we cultivated hematopoietic colonies in parallel as controls. These data indicated a $74 \pm 15 \%$ reduction of CFU-GM in the presence of antibody and complement versus complement only $(n=3$ separated donors, each condition cultivated in triplicate). Whereas hematopoietic cells were reduced, BPPC were not effected by anti-MY 10 treatment. Indeed, the data suggests that an inhibitory cell may be removed by MY-10 depletion (Table I).

Alternatively, we depleted MY 10-positive cells by immunoadherence (to anti-IgG coated petri dishes). These data corroborated the cytotoxicity data, in that the MY $10+$ cells failed to grow under the same serum-free conditions which support the proliferation of BPPC (not shown). We believe that both of these studies suggest that BPPC evolve from MY 10-negative cells. However, we interpret these observations with some caution as neither are conclusive. 

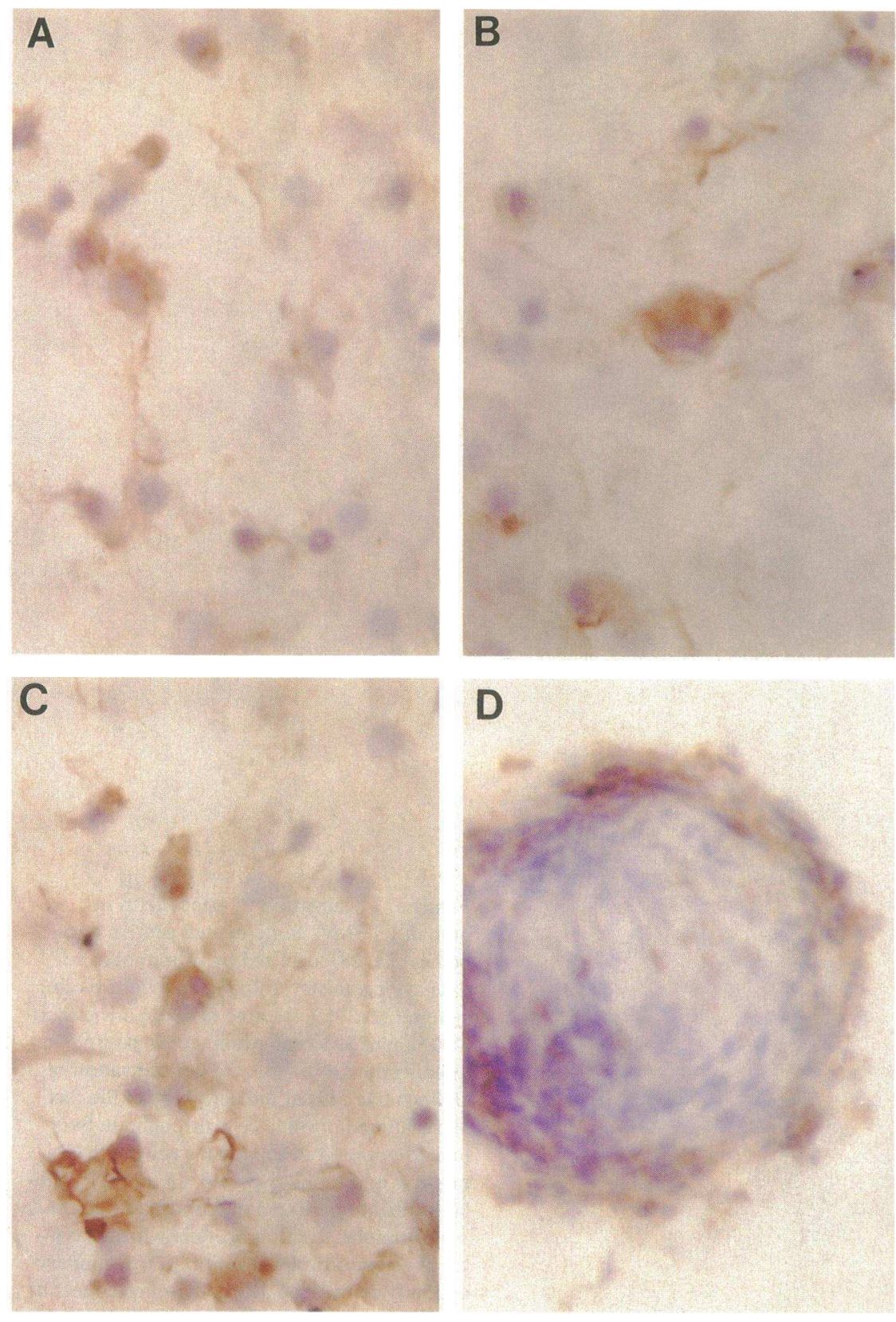

Figure 2. Bone gla protein localization in human LTBMC. Unlike ON, bone $\boldsymbol{\gamma}$-carboxyglutamic acid protein (BGP) is present as a diffuse cytoplasmic reaction product $(A-C)$. (D) A large hematopoietic foci with BGP-positive cells restricted to peripheral region and essentially negative core regions. Methods as in text. Identical results have been observed in five separate marrow donors.
Antigenic expression of bone proteins by bone-protein producing cells. To confirm our immunocytochemical observations and obtain quantitative data on bone protein expression, we also examined serum-free, short-term human bone marrow cultures for SAOS2-P80, osteonectin, and BGP production, utilizing a solid-phase radioimmunoassay (SPRIA) developed in this laboratory (27). Examination of unstimulated input marrow cells indicates that ON and BGP are not detected by RIA, whereas low amounts of the SAOS2-P80 antigen are seen (Fig. $3 \mathrm{~A}$ ). Cultivation of (unstimulated) marrow cells under serum-free conditions results in increased surface expression on ON, BGP, and SAOS2-P80 among adherent cells. These data confirm and extend our immunocytochemical data by showing that adherent BPPC constitutively express bone proteins within the hematopoietic microenvironment. Importantly, they also are the first to show the expression of SAOS2-
P80 in nontransformed cells, and suggest that this antigen may be developmentally regulated during osteopoiesis. Whether a single cell population coexpresses each of these antigens or multiple bone protein-producing lineages exist remains to be determined. Nonetheless, the RIA data are consistent with immunocytochemical observations.

Growth factor responsiveness of bone protein producing cells. TGF- $\beta$ is the prototype of a family of multifunctional regulatory peptides with diverse effects on cellular function $(33,34)$. Importantly, it is a negative modulator of hematopoietic cell proliferation which is produced by hematopoietic (and other) cells, blood platelets being the most concentrated source of TGF- $\beta$ in the body (33). Moreover, TGF- $\beta$ is found in high quantity in bone, suggesting that bone contains the greatest total amount of TGF- $\beta(34,35)$. TGF- $\beta$ stimulates cartilage formation, is synthesized and secreted in bone cell cultures, 
Table I. Bone Protein Producing Cells (BPPC) Lack a MY 10 Phenotype

\begin{tabular}{lccr}
\hline & \multicolumn{3}{c}{ Antigenic phenotype (percent positive) } \\
\cline { 2 - 4 } & SAOS2 & \multicolumn{1}{c}{ BGP } & ON \\
\hline Control & 7.4 & 6.2 & 2.2 \\
Anti-MY 10 & 9.5 & 19.2 & 10.3 \\
\hline
\end{tabular}

Human NALD cells were treated with complement (controls) or anti-MY 10 and complement in a typical cytotoxicity assay, and cultivated (in the absence of stimuli) as described in Methods. Subsequently, the cells were subjected to immunoperoxidase labeling and quantitated based on 500 cell differentials. Results are from a single donor based on triplicate replicate cultures per condition.

and stimulates the growth of subconfluent layers of fetal bone cells, thus showing it to be an autocrine regulator of bone development (33). We examined the ability of TGF- $\beta$ to regulate the bone protein expression in short-term human bone marrow cell cultures. Picogram concentrations (10-50 pM) of this regulator markedly increased the number of bone protein-positive cells observed by immunocytochemistry, resulting in a 6-10-fold increase in BPPC numbers (Fig. $3 \mathrm{~B}$ ). Conversely, BPPC were not affected by the recombinant hematopoietic growth factors: interleukins-1,3, or 6 nor GM-CSF (Table II). Thus, the increase in BPPC numbers in stimulated adherent cell populations shows that TGF- $\beta$ is an important modulator of bone protein expression within the hematopoietic microenvironment, and their lack of hematopoietic factor responsiveness further distinguishes them from hematopoietic progenitor cells.
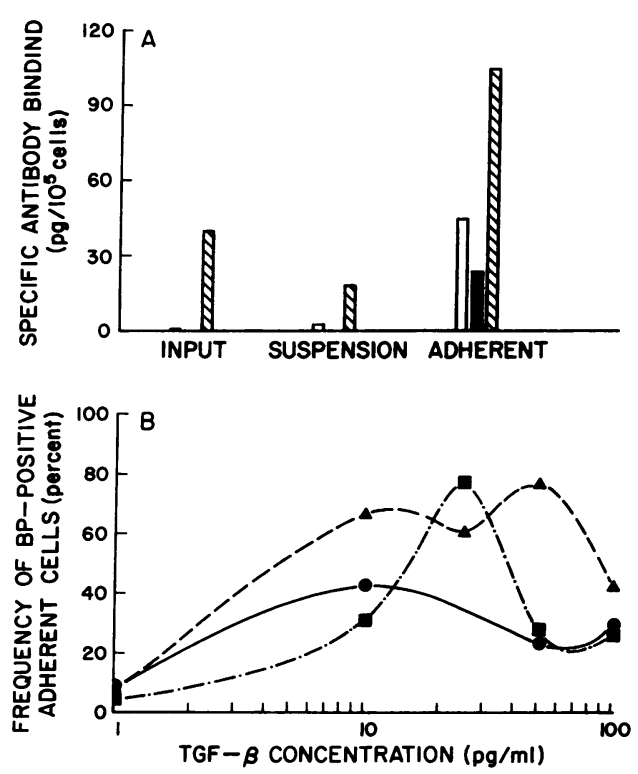

Figure 3. Bone-related protein expression in short-term serum-free cultures. Bone expression determined by solid-phase RIA as described elsewhere $(25,27)$ using monoclonal antibodies to human bone-related proteins. For simplicity, variability indices are not shown but are $<10 \%$ intraassay, and 35\% between donors. $(A)$ Unstimulated cultures. (Open bars) BGP; (solid bars) ON; (hatched bars) SAOS2-P80. (B) TGF- $\beta$ stimulated cultures (suspension cells). (Circles) BGP; (squares) SAOS2-P80; (triangles) ON.
Table II. Characterization of Bone Marrow-derived Bone Protein-producing Cells In Vitro

\begin{tabular}{ll}
\multicolumn{1}{c}{ Unstimulated cultures } & B.P. expression \\
\hline $\begin{array}{l}\text { Input Marrow } \\
\text { hu-LTBMC }(\mathrm{n}=5)\end{array}$ & $\begin{array}{l}\text { Negative/rare } \\
\text { Positive }\end{array}$ \\
$\begin{array}{l}\text { Short-term, serum-free cultures } \\
\text { NALD cells }(n=4)\end{array}$ & $\begin{array}{l}\text { Positive } \\
\text { Adherent cells }(n=4)\end{array}$ \\
MY-10 negative NALD $(n=2)$ & $\begin{array}{l}\text { Negative } \\
\text { Positive }\end{array}$ \\
$\quad$ Stimulated serum-free cultures & Responsiveness \\
\hline Hematopoietic growth factors, (r-hu-IL1, IL3, & \\
$\quad$ IL-6, or GM-CSF $(n=5)$ & Negative \\
1,25-OH vitamin $\mathrm{D}_{3}(n=5)$ & Moderate \\
TGF- $\beta(n=8)$ & \\
Suspension cells & Low-moderate \\
Adherent cells & High
\end{tabular}

Serum-free human NALD cells were established in short-term $(7 \mathrm{~d})$ cultures as described in Fig. 3. The numbers $(n)$ represent the total number of individual bone marrow donors examined for bone protein expression in each condition. Serum-free bone protein-producing cells have been observed in 21 separate donors and five separate donors for long-term marrow cultures. (a) Input NALD marrow cells contain $\simeq 100-300 / 10^{5}$ BP-positive cells as determined by FITC-labeled flow cytometry studies (not shown). hu-LTBMC, human longterm marrow cell cultures; NALD, nonadherent, low-density cells; BP, bone protein; r, recombinant; hu, human; IL, interleukin.

Osteoblastlike differentiation of marrow-derived bone protein producing cells. Further documentation of the osteal nature of BPPC was observed after the addition of serum to 7-d-old serum-free cultures. Serum repletion stimulated BPPC to differentiate into large osteoblastlike cells (Fig. $4 \mathrm{~A}$ ). These cells morphologically resemble marrow-derived osteoblasts (36), having abundant, foamy cytoplasm and a single, eccentric nucleus. Immunocytochemical analysis revealed that these cells continue to express low amounts of cytoplasmic bone-related protein (ON; BGP; SAOS2-P80, and $\alpha_{2}$ HS-GP), and, importantly, deposit bone-related proteins in the extracellular matrix (ECM) (Fig. 4, $B$ and $C$ ). A macrophage phenotype was ruled out as these cells fail to express (either constitutively or TGF- $\beta$ stimulated) the MO- 1 antigen, (which is found on granulocytes, monocytes, and tissue macrophages [37]) and are nonspecific esterase and NBT-reductase negative. Finally, immunocytochemical studies indicate that these cells express type I and type III collagen (not shown) further confirming both their osteal nature and ruling out a macrophage phenotype as these collagens are not expressed by macrophages.

The extracellular deposition of bone-related proteins suggests that these cells are organizing the ECM in an osteogenic fashion, i.e., bone protein is incorporated into the matrix antecedent to, or coincident with mineralization. Consistent with this hypothesis, the ECM surrounding these cells is positive for the von Kossa reaction (Fig. $4 \mathrm{D}$ ), which detects the presence of calcium phosphates in mineralized tissue (38). Further, these cells deposit radiolabeled calcium $\left({ }^{45} \mathrm{Ca}^{2+}\right)$ into the $E C M$, showing a 10-100-fold increase in incorporation over $8 \mathrm{~d}$ of culture (Table III). 

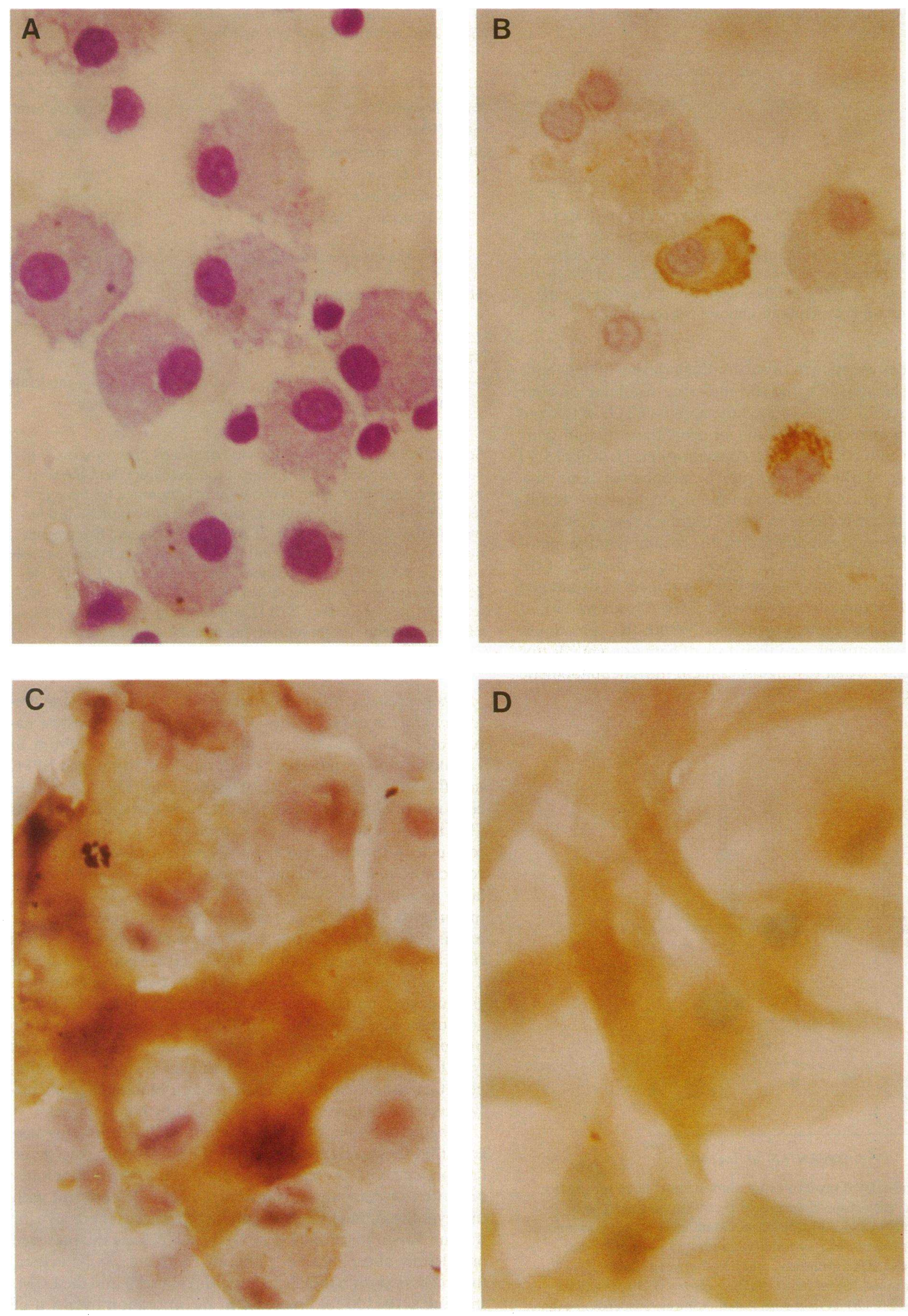

1392 M. W. Long, J. L. Williams, and K. G. Mann 
Table IIr. "Cand

Table III. ${ }^{45} \mathrm{Ca}^{++}$Incorporation into Extracellular Matrix

\begin{tabular}{lccc}
\hline & \multicolumn{3}{c}{${ }^{45} \mathrm{Ca}^{++}$incorporation (DPM) } \\
\cline { 2 - 4 } \multicolumn{1}{c}{ Procedure } & Day 3 & Day 6 & Day 8 \\
\hline EDTA/trypsin extract & NT & 71,165 & 186,798 \\
Triton X-100 extract & 1,700 & 20,400 & 12,094 \\
Total & 1,700 & 91,568 & 198,842 \\
& & & \\
\hline
\end{tabular}

Calcium $\left({ }^{45} \mathrm{Ca}^{++}\right)$incorporation into the ECM of serum-stimulated BPPC. Equivalent cell numbers were seen on each day of culture so data is not normalized for cellularity. Results are mean DPM per culture of three separate determinatons from a single representative donor of two separate donors. Each extraction procedure was performed sequentially. Methods: BPPC were cultivated under serumfree conditions and serum stimulated on day 7 as described in Fig. 4. On days 3,6 , and 8 post-serum stimulation, the suspension and adherent cells were removed and washed three times with calcium-free PBS, and metabolically labeled with $50 \mu \mathrm{Ci}^{45} \mathrm{Ca}^{++}$(as $\mathrm{CaCl}_{2}$; Amersham Corp.; sp act $733 \mathrm{mBq} / \mathrm{Mg}$ ) for $60 \mathrm{~min}$ at $37^{\circ} \mathrm{C}$. After calcium equilibration, labeled cells were washed free of unincorporated calcium, resuspended in tissue culture medium (RPMI 1640, Gibco, Grand Island, NY), reestablished in the original cultures, and allowed to incorporate cellular ${ }^{45} \mathrm{Ca}^{++}$into the ECM for $60 \mathrm{~min}$ at $33^{\circ} \mathrm{C}$. Subsequently, cells/ECM were removed with trypsin/EDTA (as in Fig. 3), cells pelleted by centrifugation, and ${ }^{45} \mathrm{Ca}^{++}$incorporation into the trypsin/EDTA extractable ECM determined by scintillation counting. Trypsin-resistant ECM was removed by Triton $X-100$ extraction as described previously $(30,31)$ and counted similarly. Total extractable counts on day 3 were determined using a single Triton X-100 extract. NT, not tested.

In summary, these culture systems document the presence of a new marrow cell phenotype capable of elaborating bonerelated proteins, osteoblastlike differentiation, and bonelike organization of the ECM. In LTBMC, which are replete with serum and contain heterogeneous cell populations, BPPC are developmentally regulated, and regionally restricted in their distribution. In short-term, serum-free cultures, these cells evolve from NALD input cells as an adherent cell phenotype with a limited capacity to proliferate but which nonetheless express bone-related proteins, and respond to TGF- $\beta$ with a marked increase in proliferation. Subsequently, these cells respond to undefined serum factor(s) with osteoblastlike differentiation and matrix deposition. The nature of the serum regulator(s) is unknown, but it is not mimicked by the addition of TGF- $\beta$ or $1,25-\mathrm{OH}$ vitamin $\mathrm{D}_{3}$ to serum-free cultures (not shown).

Our observations do not exclude a role for other marrow cells in osteogenesis. Previous reports by both Owen and Friedenstein demonstrated the osteogenic potential of bone marrow (for a review see reference 39 ). These studies documented

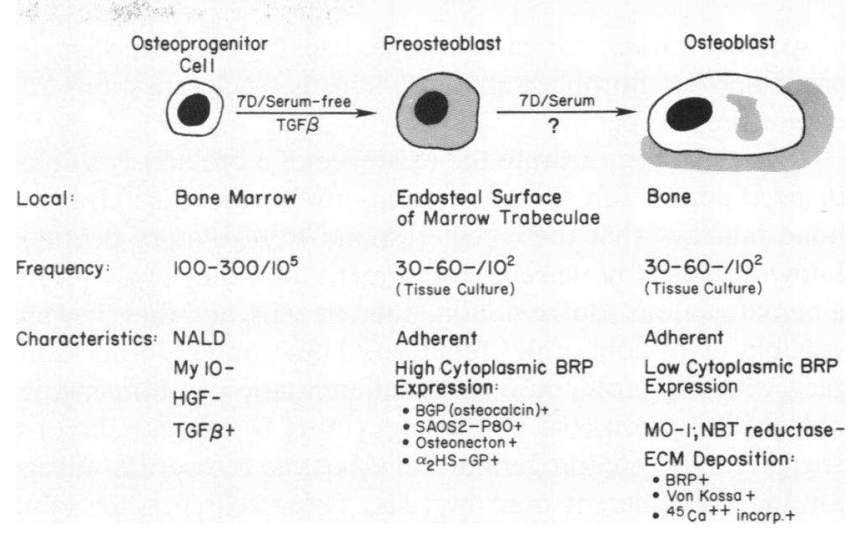

Figure 5. Hypothetical model of bone marrow-derived BPPC development. This model proposes that unrecognizable osteoprogenitor cells exist among the marrow nonadherent cell populations. These cells are highly proliferative in the presence of bone-related regulators such as TGF- $\beta$. Such a lineage expansion results in the presence of immature cells which contain high levels of cytoplasmic bone-related proteins. In this model, the progeny of the osteoprogenitor cell cells are the preosteoblasts which are adherent and express cytoplasmic bone proteins. These BPPC in turn respond to unknown serum regulators by begining to differentiate into osteoblastlike cells which deposit bone proteins and calcium into the ECM. 7D, $7 \mathrm{~d}$ in culture; TGF- $\beta$, transforming growth factor- $\beta$; serum, serum repletion of cultures; NALD, nonadherent low density cells; HGF, hematopoietic growth factors; BRP, bone-related proteins; BGP, SAOS2-P80, HS-GP as in text; MO-1, a granulocyte, macrophage antigenic marker, NBT, nitrotoledine blue; +, positive responsiveness; -, negative responsiveness.

that organ cultures of murine marrow, or marrow stromal cells, have bone-forming potential both in vivo (using diffusion chambers) and in vitro $(7,40,41)$. These investigators further identified an osteogenic cell phenotype in a subpopulation of adherent bone marrow fibroblasts, localized near the (endosteal) bone surface $(40,42)$. These cells are the progeny of fibroblast colony-forming cells (CFC-F) which are serumresponsive, generate heterogeneous populations of cells, and are strongly adherent (43-46). In sharp contrast, our observations of human BPPC show that these putative osteoprogenitor cells are nonadherent (i.e., are not found among adherent stromal cells), proliferate under serum-free conditions, are nonresponsive to hematopoietic regulators, but do respond to bone-related growth factors (Fig. 5). Human BPPC also develop under temperature conditions which are restrictive to CFC-F proliferation $\left(33^{\circ} \mathrm{C}\right.$ vs. $37^{\circ} \mathrm{C}$, respectively), (47). Finally, human cells producing bone proteins lack distinct fibroblast characteristics being morphologically similar to (pre)osteoblasts. Whether a relationship exists between BPPC and cells of other lineages such as fibroblasts will require coanalysis

Figure 4. Serum-induced osteoblastlike differentiation of bone protein producing cells. Exposure of BPPC, previously cultivated for $7 \mathrm{~d}$ in serum-free cultures, to $10 \%$ fetal calf serum (FCS) results in an osteoblastlike differentiation. $(A)$ Romanovski staining of serum-stimulated BPPC. $(B)$ Bone gla protein expression in serum-stimulated BPPC. $(C)$ Extracellular deposition of BGP in ECM surrounding serum-induced BPPC. $(D)$ The von Kossa reaction showing calcium phosphate deposition (yellow/tan coloration; nuclei are counterstained green; see reference 38) in ECM surrounding BPPC. Immunoperoxidase was performed as in Methods. The von Kossa reaction was performed and described previously and shows the typical yellow/dark tan positive reaction product due to calcium phosphate (38). Cells pictured are from a single donor representative of eight separate donors examined for BPPC serum-responsiveness (except for the von Kossa reaction which was observed in two donors). 
of specific markers for each lineage. Lacking such markers, in particular for fibroblast progenitor cells, such questions remain unresolved.

Our data demonstrate the existence of a previously unrecognized population of bone protein-producing cells in human bone marrow, that these cells respond to regulatory peptides known to affect bone cell development, that they evolve from a hematogenous source of nonadherent cells, and that they are capable of osteoblastlike function. These observations, coupled with the proliferation and differentiation of unrecognizable BPPC precursors in the input NALD cell populations, suggests that osteoprogenitor cells exist as a separate lineage among nonadherent marrow cells. These cells become bone associated (i.e., adherent) under osteopoietic regulatory influences such as TGF- $\beta$ (Fig. 5). Whereas this hypothesis remains to be proven, marrow-derived BPPC nonetheless provide a valuable model for studies on the regulation of bone protein production in health and disease.

\section{Acknowledgments}

The authors are indebted to Drs. Vishva Dixit and Barbara Grant for advice on the manuscript, Dr. J. Smolen for advice on ${ }^{45} \mathrm{Ca}^{2+}$ in corporation studies, Dr. Paul Killen and Dr. Jeffery Bonadio for their generous gift of antibodies to type I and III collagen, and Ms. Jennie McAlpine for careful preparation of the manuscript.

This work has been supported in part by grants \#HL 35225 and \#AG 04875 from the National Institutes of Health.

\section{References}

1. Song, Z. X., R. K. Shadduck, D. J. Innes, Jr., A. Waheed, and P. J. Quesenberry. 1985. Hematopoietic factor production by a cell line (TC-1) derived from adherent murine marrow cells. Blood. 66:273-281.

2. Dexter, T. M., and L. G. Lajtha. 1974. Proliferation of haemopoietic stem cells in vitro. Br. J. Haematol. 28:525-530.

3. Dexter, T. M. 1982. Stromal cell associated haemopoiesis. J. Cell Physiol. 1:87-94.

4. Hattersley, G., and T. J. Chambers. 1989. Generation of osteoclastic function in mouse bone marrow cultures: multicellularity and tartarate resistant acid phosphatase are unreliable markers of osteoclastic differentiation. Endocrinology. 124:1689-1696.

5. Knospe, W. H., S. G. Husseini, and W. Fried. 1989. Hematopoiesis on cellulose ester membranes. XI. Induction of new bone and a hematopoietic microenvironment by matrix factors secreted by marrow stromal cells. Blood. 74:66-70.

6. Benayhahu, D., Y. Kletter, D. Zipori, and S. Weintraub. 1989. Bone marrow-derived stromal cell line expressing osteoblastic phenotype in vitro and osteogenic capacity in vivo. J. Cell. Physiol. 140:1-7.

7. Mardon, H. J., J. Bee, K. von der Mark, and M. E. Owen. 1987. Development of osteogenic tissue in diffusion chambers from early precursor cells in bone marrow of adult rats. Cell Tissue Res. 250:157-165.

8. Bleiberg, I., M. D. Ricciardone, H. A. Reddi, and K. F. McCarthy. 1987. New bone formation and bone marrow differentiation induced in rats by extracellular bone matrix implantation: effect of local preirradiation on the process. Exp. Hematol. (NY). 15:309315.

9. Urist, M. R., K. Sato, A. G. Brownell, T. I. Malinin, A. Lietze, Y. K. Huo, D. J. Prolo, S. Oklund, G. A. M. Finerman, and R. J. DeLange. 1983. Human bone morphogenic protein (hBMP). Proc. Soc. Exp. Biol. Med. 173:194-199.

10. Muthukumaran, N., and A. H. Reddi. 1985. Bone matrix-induced local bone induction. Clin. Orthop. Relat. Res. 200:159-164.

11. Urist, M. R., R. J. DeLange, and G. A. M. Finerman. 1983.
Bone cell differentiation and growth factors. Science (Wash. DC). 220:680-686.

12. Fishman, D. A., and E. D. Hay. 1962. Origin of osteoclasts from mononuclear leukocytes in regenerating newt limbs. Anat. Rec. 143:329-339.

13. Horton, M. A., D. Lewis, K. McNulty, J. A. Pringle, and T. J. Chambers. 1985. Monoclonal antibodies to osteoblastomas (giant cell bone tumors): definition of osteoclastic specific cellular antigens. Cancer Res. 45:5663-5669.

14. Jotereau, F. W., and N. M. Le Douarin. 1978. The developmental relationship between osteocytes and osteoblasts: a study using the quail-chick nucleus marker in endochondrial ossefication. Dev. Biol. 63:253-265.

15. Le Douarin, N. M. 1973. A feulgin-positive nucleolus. Exp. Cell Res. 77:459-469.

16. Ash, P., J. F. Loutit, and K. M. S. Townsend. 1980. Osteoclasts derived from haematopoietic stem cells. Nature (Lond.). 283:669-670.

17. Coccia, P. F., W. Krivitt, J. Cervenka, C. Clawson, J. H. Kersey, T. H. Kim, M. E. Nesbit, M. K. C. Ramasy, P. I. Warkinten, S. L. Teitelbaum, A. J. Kahn, and D. M. Brown. 1980. Successful bonemarrow transplantation for juvenile malignant osteopetrosis. N. Engl. J. Med. 302:701-708.

18. Termine, J. D., H. K. Kleinman, S. W. Whitson, K. M. Conn, M. L. McGarvey, and G. R. Martin. 1981. Osteonectin, a bone-specific protein linking mineral to collagen. Cell. 26:99-105.

19. Holland, P. W. H., S. J. Harmper, J. H. McVey, and B. L. M. Hogan. 1987. In vivo expression of mRNA for the $\mathrm{Ca}^{++}$-binding protein SPARC (osteonectin) revealed by in situ hybridization. J. Cell Biol. 105:473-482.

20. Nomura, S., A. J. Wills, D. R. Edwards, J. K. Heath, and B. L. M. Hogan. 1988. Developmental expression of 2ar (osteopontin) and SPARC (osteonectin) RNA as revealed by in situ hybridization. $J$. Cell Biol. 106:441-450.

21. Price, P. A., A. S. Otsuka, J. W. Poser, J. Kristaponis, and N. Raman. 1976. Characterization of a gamma-carboxyglutamic acidcontaining protein from bone. Proc. Natl. Acad. Sci. USA. 73:14471451.

22. Stenner, D. D., R. W. Romberg, R. P. Tracy, J. A. Katzman, B. L. Riggs, and K. G. Mann. 1984. Monoclonal antibodies to native noncollagenous bone-specific proteins. Proc. Natl. Acad. Sci. USA. 81:2868-2872.

23. Shull, S., R. P. Tracy, and K. G. Mann. 1989. Identification of a vitamin $\mathrm{D}$ responsive protein on the surface of human osteosarcoma cells. Proc. Natl. Acad. Sci. USA. 86:5405-5410.

24. Gartner, S., and H. S. Kaplan. 1980. Long-term culture of human bone marrow cells. Proc. Natl. Acad. Sci. USA. 77:4756-4759.

25. Long, M. W., R. J. Hutchinson, L. L. Gragowski, C. H. Heffner, and S. G. Emerson. 1988. Synergistic regulation of human megakaryocyte development. J. Clin. Invest. 82:1779-1786.

26. Long, M. W., and D. N. Shapiro. 1985. Immune regulation of in vitro murine megakaryocyte development. Role of T lymphocytes and Ia antigen expression. J. Exp. Med. 162:2053-2067.

27. Long, M. W., and C. H. Heffner. 1988. Detection of human megakaryocyte antigens by solid-phase radioimmunoassay. Exp. $\mathrm{He}$ matol. 16:62-70.

28. Roberts, R., J. Gallagher, E. Spooncer, T. D. Allen, and T. M. Dexter. 1988. Heparin sulfate bound growth factors: a mechanism for stromal cell mediated haemopoiesis. Nature (Lond.). 332:376-378.

29. Hsu, S. M., L. Raine, and H. Fanger. 1981. The use of avidinbiotin-peroxide complex $(\mathrm{ABC})$ in immunoperoxidase techniques: a comparison between $\mathrm{ABC}$ and unlabeled antibody (PAP) procedures. J. Histochem. Cytochem. 29:577-580.

30. Gospodarowicz, D., and C. Ill. 1980. Extracellular matrix and control of proliferation of vascular endothelial cells. J. Clin. Invest. 65:1351-1364.

31. Gospodarowicz, D., D. Delagado, and I. Vlodavsky. 1980. Permissive effect of the extracellular matrix on cell proliferation in vitro. Proc. Natl. Acad. Sci. USA. 77:4094-4098. 
32. Foon, K. A., R. P. Gale, and R. F. Todd. 1986. Recent advances in the immunologic classification of leukemia. Semin. Hematol. 23:257-283.

33. Sporn, M. B., and A. B. Roberts. 1985. Autocrine growth factors and cancer. Nature (Lond.). 313:745-747.

34. Massague, J. 1987. The TGF-beta family of growth and differentiation factors. Cell. 49:437-438.

35. Gehron Robey, P., M. F. Young, K. C. Flanders, N. S. Roche, P. Kondaiah, A. H. Reddi, J. D. Termine, M. B. Sporn, and A. B. Roberts. 1987. Osteoblasts synthesize and respond to transforming growth factor-type beta (TGF-beta) in vitro. J. Cell Biol. 105:457-463.

36. Zucker-Franklin, D., M. F. Greaves, C. E. Grossi, and A. M. Marmont. 1981. Atlas of Blood Cells: Function and Pathology. Lea and Febiger, Philadelphia.

37. Todd III, R. F., M. J. Bury, and D. Y. Liu. 1987. Expression of an activation antigen, Mo3e, associated with the cellular response to migration inhibitory factor by HL-60 promyeolocytes undergoing monocyte-macrophage differentiation. J. Leuk. Biol. 41:492-499.

38. Puchtler, H., and S. N. Meloan. 1978. Demonstration of phosphates in calcium deposits: a modification of von Kossa's reaction. Histochemistry. 56:177-185.

39. Owen, M., and A. J. Friedenstein. 1988. Stromal stem cells: marrow-derived osteogenic precursors in cell and molecular biology of vertebrate hard tissues. CIBA Found. Symp. 136:42-60.

40. Bab, I., B. A. Ashton, D. Gazit, G. Marx, M. C. Williamson, and M. E. Owen. 1986. Kinetics and differentiation of marrow stromal cells in diffusion chambers in vivo. J. Cell Sci. 84:139-151.
41. Luria, E. A., M. E. Owen, A. J. Friedenstein, J. F. Morris, and S. A. Kuznetsow. 1987. Bone formation in organ cultures of bone marrow. Cell Tissue Res. 248:449-454.

42. Ashton, B. A., C. C. Eaglesom, I. Bab, and M. E. Owen. 1984. Distribution of fibroblastic colony-forming cells in rabbit bone marrow and assay of their osteogenic potential by an in vivo diffusion chamber method. Calcif. Tissue. Int. 36:83-86.

43. Castro-Malaspina, H., E. M. Rabellino, A. Yen, R. L. Nachman, and M. A. S. Moore. 1981. Human megakaryocyte stimulation of proliferation of bone marrow fibroblasts. Blood. 57:781-787.

44. Owen, M. E., J. Cave, and C. J. Joyner. 1987. Clonal analysis in vitro of osteogenic differentiation of marrow CFU-F. J. Cell Sci. 87:731-738.

45. Castro-Malaspina, H., R. E. Gay, G. Resnick, N. Kapoor, P. Meyers, D. Chairieri, S. McKenzie, H. E. Broxmeyer, and M. A. S. Moore. 1980. Characterization of human bone marrow fibroblast colony-forming cells and their progeny. Blood. 56:289-301.

46. Friedenstein, A. J., R. K. Chailakhyan, N. V. Latsinik, A. F. Panasyuk, and I. V. Keiliss-Borok. 1974. Stromal cells responsible for transplanting the microenvironment of the bone marrow. Transplantation (Baltimore). 17:331-340.

47. Castro-Malaspina, H., W. Ebell, and S. Wang. 1984. Human bone marrow fibroblast colony-forming units (CFU-F). In Myelofibrosis and the Biology of Connective Tissue. P. D. Berk, H. Castro-Malaspina, and L. R. Wasserman, editors. Alan R. Liss, Inc., New York. 209-236. 